\title{
Short communication: Effect of casein haplotype on angiotensin-converting enzyme inhibitory and antioxidant capacities of milk casein from Italian Holstein cows before and following in vitro digestion with gastrointestinal enzymes
}

\section{Annamaria Perna, ${ }^{1}$ Amalia Simonetti, and Emilio Gambacorta}

School of Agricultural, Forestry, Food and Environmental Sciences, University of Basilicata, Potenza, Viale dell'Ateneo Lucano 10 - 85100 , Italy

\begin{abstract}
The aim of this work was to investigate the effect of casein haplotype $\left(\alpha_{\mathrm{S} 1}, \beta\right.$, and $\left.\kappa\right)$ on antioxidative and angiotensin-converting enzyme (ACE) inhibitory capacities of milk casein from Italian Holstein cows before and following in vitro digestion with gastrointestinal enzymes. The antioxidant capacity was measured using 2,2'-azino-bis-3-ethylbenzothiazoline-6-sulfonic acid and ferric-reducing antioxidant power assays, whereas ACE inhibition was determined by ACE-inhibitory assay. The ACE-inhibitory and antioxidant capacities of milk casein increased during in vitro gastrointestinal digestion. Casein haplotype significantly influenced the antioxidative and ACE-inhibitory capacities of digested casein. In particular, $B B-A^{2} A^{1}-A A$ casein and $B B-A^{1} A^{1}$ $A A$ casein showed the highest ACE-inhibitory capacity, $B B-A^{2} A^{2}-A A$ casein showed the highest antioxidant capacity, whereas $B B-A^{2} A^{2}-B B$ casein showed the lowest biological capacity. To date, few studies have been done on the effect of casein haplotype on biological capacity of milk casein, thus the present study sets the basis for a new knowledge that could lead to the production of milk with better nutraceutical properties.
\end{abstract}

Key words: casein haplotype, ACE-inhibitory capacity, antioxidant capacity, Italian Holstein milk

\section{Short Communication}

Many studies have highlighted the nutraceutical effect of some milk compounds in the human body (AlbertiFidanza et al., 2002; Silva and Malcata, 2005; Phelan et al., 2009) such as $\alpha_{\mathrm{S1}^{-}}, \alpha_{\mathrm{S}^{-}}, \beta-$, and $\kappa-\mathrm{CN}$ (CSN1S1, CSN1S2, CSN2, and CSN3 gene loci, respectively), which are biologically active peptides that can have health-promoting properties. These bioactive peptides are released from milk casein sequences mostly during

Received February 16, 2016.

Accepted May 4, 2016.

${ }^{1}$ Corresponding author: anna.perna@unibas.it gastrointestinal digestion by gastric and pancreatic enzymes (Chabance et al., 1995, 1998), whereas others can be released in an active form by enzymes during milk processing and are, therefore, naturally present in dairy products (Smacchi and Gobbetti, 2000). Casein-derived peptides have shown a range of biological activities, such as antihypertensive, antioxidant, antithrombotic, antimicrobial, opioid, immune-modulating, and mineral-binding properties (Silva and Malcata, 2005; Phelan et al., 2009). Some peptides can combine more than one of these effects, resulting in multifunctional structures which have broader applications in health maintenance (Corrêa et al., 2011). Maruyama et al. (1987) reported that peptides derived from tryptic hydrolysis of $\alpha_{\mathrm{S}^{-}} \mathrm{CN}$ (fragments 23-24, 23-27, and 194-199) and of $\beta-\mathrm{CN}$ (fragments 177-183 and 193-202), known as casokinins, inhibited angiotensin I-converting enzyme (ACE; EC 3.4.15.1) activity. Angiotensin I-converting enzyme is a key enzyme in the regulation of blood pressure; in particular, ACE catalyzes the conversion of angiotensin I into angiotensin II, a potent vasoconstrictor, and inactivates bradykinin, a vasodilator (Ondetti and Cushman, 1977). The inhibition of ACE is a method widely used for the treatment of hypertension (Conlin, 2001). It has been reported that the antioxidant capacity of caseins is related to their high tendency to chelate metals (Tong et al., 2000; Rival et al., 2001), and to their ability to donate electrons and atoms (Colbert and Decker, 1991). The bioactive potential of the casein depends on its AA sequence, which is conditioned by genetic polymorphism. The degree of casein heterogeneity may influence the release of peptides formed during proteolysis (Minervini et al., 2003; Hernández -Ledesma et al., 2004; De Noni et al., 2009); this is due to the presence in the casein of specific sequences, known as strategic zones, that have biological activities (Fiat and Jolles, 1989). Milk caseins occur in different allelic forms controlled by codominant genes (CSN1S1, CSN2, CSN1S2, and CSN3) tightly linked in a 250-kb cluster mapped on chromosome 6 (Ferretti et al., 1990; Caroli et al., 2009). Until a few years ago, the associa- 
tion between the genetic forms of a single locus and the milk characteristics was the approach used (Di Stasio and Mariani, 2000; Martin et al., 2002). Currently, it is believed that a better estimation of effects is obtained when considering the whole casein cluster instead of the single casein loci within a single breed (Beja-Pereira et al., 2002; Boettcher et al., 2004; Gambacorta et al., 2005). In this regard, the aim of our study was to estimate the effect of casein haplotype on ACE-inhibitory and antioxidant capacities of milk casein from Italian Holstein cows before and following in vitro digestion with gastrointestinal enzymes.

This study was conducted on an intensive farm, consisting of more than 500 Italian Holstein cattle, in the countryside of Potenza, southern Italy. Before starting the test, approximately 250 animals in lactation were identified by isoelectric focusing to define their haplotypes (Perna et al., 2013). Haplotypes were formed by the combination of the individual allelic loci aggregated by $\alpha_{\mathrm{S1}^{-}}, \beta-$, and $\kappa^{-} \mathrm{CN}$. After defining the individual phenotypes, the cows were grouped by haplotype. Each group was formed by 10 to 12 animals, an equal stage of lactation (70-120 d postpartum), season (spring), and order of birth (third calving). All animals were fed a commercial standard diet according to milk yield. The individual cow milk of the morning milking was collected once and all milk samples were analyzed within $3 \mathrm{~h}$ from collection. Individual milk samples were skimmed by centrifugation $(6,000 \times g$ for $20 \mathrm{~min}$ at $\left.4^{\circ} \mathrm{C}\right)$, diluted with distilled water $(1: 4, \mathrm{vol} / \mathrm{vol})$, and the $\mathrm{pH}$ of solution was adjusted to 4.6 with $1 \mathrm{~N} \mathrm{HCl}$ for casein precipitation. After centrifugation at $3,000 \times g$ for $10 \mathrm{~min}$ at $4^{\circ} \mathrm{C}$, the casein pellet was resuspended in distilled water and casein was solubilized by adjusting the $\mathrm{pH}$ to 7.5 with $1 \mathrm{~N} \mathrm{NaOH}$. Each precipitation was repeated 3 times. Then, the purified casein was lyophilized and stored at $-20^{\circ} \mathrm{C}$ until analysis. The in vitro gastrointestinal digestion of the lyophilized casein was simulated using pepsin and trypsin according to the method of Ao and $\mathrm{Li}$ (2013), with some modifications. Three hundred milligrams of lyophilized casein was mixed with $27 \mathrm{~mL}$ of bidistilled water, the $\mathrm{pH}$ was adjusted to 2 with $1 \mathrm{~N} \mathrm{HCl}$, and the stomach phase was simulated by adding pepsin (Sigma-Aldrich, Milan, Italy) at a 1:200 (enzyme:substrate) ratio. After $2 \mathrm{~h}$ of digestion at $37^{\circ} \mathrm{C}$ and continuous stirring, the enzyme was inactivated by adjusting the $\mathrm{pH}$ to 7.5 with $1 \mathrm{~N}$ $\mathrm{NaHCO}_{3}$. Then, trypsin (Sigma-Aldrich) was added at a 1:25 (enzyme:substrate) ratio to simulated the intestinal phase. After $4 \mathrm{~h}$ of digestion at $37^{\circ} \mathrm{C}$, enzyme activity was terminated by heating for $10 \mathrm{~min}$ at $95^{\circ} \mathrm{C}$. Samples were collected before adding the enzymes, after pepsin (120 min) and trypsin (240 min) digestion. Each sample was centrifuged at $5,000 \times g$ for 20 min at $4^{\circ} \mathrm{C}$ to remove large particles, the supernatant was filtered through a $0.2-\mu \mathrm{m}$ cellulose acetate membrane filter (Sigma-Aldrich), and it was frozen and kept a $-55^{\circ} \mathrm{C}$ until analysis. The ACE-inhibitory capacity was measured by the spectrophotometric assay of HernándezLedesma et al. (2005). The $\mathrm{IC}_{50}$ values were calculated as the concentration $(\mu M)$ of the sample required to inhibit $50 \%$ of ACE capacity and was tested in triplicate. The antioxidant capacity of casein was determined by 2,2'-azino-bis-(3-ethylbenzthiazoline-6-sulfonic acid) (ABTS) radical scavenging and ferric-reducing antioxidant power (FRAP) assays. The ABTS assay was determined according to the method of Re et al. (1999), as modified by Perna et al. (2013); FRAP assay was determined according to the method of Benzie and Strain (1996). Each determination and measurement was made in triplicate and the results for both assays were expressed as milligrams of Trolox equivalent (TE) per milligram of casein. Data were analyzed according to the following linear model (SAS Institute, 1996):

$$
y_{i k}=\mu+\alpha_{i}+\varepsilon_{i k}
$$

where $y_{i k}$ is the observation; $\mu$ is the overall mean; $\alpha_{i}$ is the fixed effect of the $i$ th haplotype $(i=1,2,3$, $4,5)$; and $\varepsilon_{i k}$ is the random error. Before setting the values, expressed as a percentage, they were subjected to angular transformation. Student's $t$-test was used to compare all variables. Differences between means at the $95 \%(P<0.05)$ confidence level were considered statistically significant.

In our study, unhydrolyzed casein $(t=0 \mathrm{~min})$ did not show ACE-inhibitory capacity $\left(\mathrm{IC}_{50}>1,000 \mu M\right)$, whereas the casein samples after in vitro pepsin $(t=$ $120 \mathrm{~min})$ and trypsin $(t=240 \mathrm{~min})$ digestion showed ACE inhibition (Table 1). The ACE-inhibitory capacity is influenced by the casein haplotype $(P<0.001)$; this finding is supported by De Noni et al. (2009), who showed that the genetic polymorphism influenced the type of bioactive peptides released from milk proteins. The ACE inhibition increased during in vitro digestion with gastrointestinal enzymes. The greatest increase of ACE-inhibitory capacity was detected between undigested and pepsin-digested casein, in agreement with what reported by López-Expósito et al. (2007) in hydrolyzed ovine casein with pepsin. With regard to casein haplotype, after pepsin digestion (120 min) $B B-A^{2} A^{2}-B B$ casein showed the lowest ACE-inhibitory capacity $(P<0.05)$, whereas $B B-A^{1} A^{1}-A A$ casein showed the highest capacity $(P<0.05)$. This could be due to the specificity of the casein molecular structure determined by genetic variants (Raynes et al., 2015) that, altering the cleavage sites, can facilitate or not the attack of protease (Petrat-Melin et al., 2014) and, 
therefore, influence the formation of ACE-inhibitory peptides. These peptides are characterized by hydrophobic, aromatic, or branched side chain AA residue at the C-terminal position (Meisel et al., 2006; Wu et al., 2006). After trypsin digestion (240 min), ACE inhibition of casein samples greatly increased (Table 1). In particular, $B B-A^{1} A^{1}-A A$ and $B B-A^{2} A^{1}-A A$ caseins showed the highest capacity $(P<0.05)$, whereas $B B-A^{2} A^{2}-B B$ casein showed the lowest percentage $(P$ $<0.05$ ). The antioxidant capacity of milk casein with different casein haplotypes before and following in vitro digestion with gastrointestinal enzymes was assessed by ABTS and FRAP assays (Table 2). The use of at least 2 different test systems for the evaluation of antioxidant capacity is necessary because of the interactions among different antioxidant components and the lack of a specific official analytical approach to determinate the antioxidant property (Moon and Shinamoto, 2009). Milk casein showed antioxidant capacity and the differences among casein haplotypes were significant $(P<$ 0.05). In particular, the average ABTS value of undigested casein was $4.24 \mathrm{mg}$ of $\mathrm{TE} / \mathrm{mg}$ of casein and the increasing sequence of radical scavenging of the milk casein with different haplotypes was $B B-A^{2} A^{2}-B B<$ $B B-A^{1} A^{1}-A A<B B-A^{2} A^{1}-A A<B B-A^{2} A^{2}-A A<B B-$ $A^{2} A^{2}-A B(P<0.05)$; whereas the average FRAP value was $0.89 \mathrm{mg}$ of $\mathrm{TE} / \mathrm{mg}$ of casein and it increased in the order of $B B-A^{2} A^{1}-A A<B B-A^{2} A^{2}-B B<B B-A^{2} A^{2}-A A$ $<B B-A^{2} A^{2}-A B<B B-A^{1} A^{1}-A A$, even if no significant differences were detected among the studied casein haplotypes. The antioxidant capacity of milk casein could be due to the high content of potentially antioxidative AA, such as tyrosine, tryptophan, histidine, lysine, and methionine (Rival et al., 2001), the polar domains of casein that contain phosphorylated serine residues (Jrad et al., 2014), and the structure of casein (Elias et al., 2008). The antioxidant capacity of milk casein increased during in vitro digestion with gastrointestinal enzymes (Table 2), in agreement with what reported by other authors (Gómez-Ruiz et al., 2008; Salami et al., 2010; Mao et al., 2011). Furthermore, casein haplotype significantly influenced the antioxidant capacity of digested casein $(P<0.05)$. In particular, after pepsin digestion $(t=120 \mathrm{~min}) B B-A^{1} A^{1}-A A$ casein showed the lowest ABTS value $(4.69 \mathrm{mg}$ of $\mathrm{TE} / \mathrm{mg}$ of casein), whereas $B B-A^{2} A^{2}-B B$ casein showed the lowest FRAP value (0.97 $\mathrm{mg}$ of TE/mg of casein). The highest ABTS and FRAP values were detected in $B B-A^{2} A^{2}$ $A A$ casein as well as in $B B-A^{2} A^{2}-A B$ and $B B-A^{1} A^{1}-A A$ casein, respectively. After trypsin digestion $(t=240$ $\mathrm{min}$ ), the average values were 5.43 and $1.30 \mathrm{mg}$ of TE/ $\mathrm{mg}$ of casein for ABTS and FRAP assays, respectively. In particular, $B B-A^{2} A^{2}-A A$ casein and $B B-A^{2} A^{2}-A B$ casein showed the highest ABTS values $(P<0.05)$, in line with what was previously detected by Perna et al. (2013) in Italian Holstein yogurt. With regard to the chelating activity, $B B-A^{2} A^{1}-A A$ casein showed the highest value $(P<0.05)$. These findings suggest that the biological capacity of milk casein is associated with the degree of casein hydrolysis, in particular, with the formation of low-molecular weight peptides (<6 kDa; Hernández-Ledesma et al., 2004; Mao et al., 2007). Furthermore, the type of bioactive peptides released from milk casein is closely influenced by the genetic polymorphism that affects the AA composition of a protein, its accessibility, and the sequence of AA (Arcan and Yemenicioğlu, 2007; Elias et al., 2008). Petrat-Melin et al. (2014) reported that the genotype can affect the presence of zones resistant to enzymatic hydrolysis positively or negatively. Lisson et al. (2013) observed that the enzymatic hydrolysis of $\beta-\mathrm{CN}$ variants $A^{1}, A^{2}$, and $B$ and of $\kappa$-CN variants $A, B$, and $E$ resulted in peptides that were unique to each variant. Moreover, Aliaga and Lissi (2000) reported that the AA with greater radical scavenger activity (cysteine, histidine, tryptophan, and tyrosine) are more present in the $\beta$-CN variants $A^{1}$ and $B$, confirming the key role of genetic polymorphism of caseins on nutraceutical quality. The variation of the biological capacity of milk casein with different casein haplotypes could be associated with genetic changes that may alter the properties of individual proteins, affect the state of aggregation of the micellar system, and interfere with the action of proteolytic enzymes (Perna et al., 2013). Moreover, a decrease of biological capacity could be due to the tendency of peptides to form macroaggregates (Adt et al., 2011) or from balance between their formation during digestion and further breakdown into inactive peptides and AA (Hajirostamloo, 2010).

Table 1. Angiotensin-coverting enzyme (ACE) inhibitory capacity $\left(\mathrm{IC}_{50}\right)$ of casein after in vitro pepsin $(t=120 \mathrm{~min})$ and trypsin $(t=$ $240 \mathrm{~min}$ ) digestion

\begin{tabular}{llllll}
\hline & \multicolumn{4}{c}{$\mathrm{IC}_{50}{ }^{1}(\mu M)$} \\
\cline { 2 - 3 } & \multicolumn{2}{c}{$\begin{array}{c}\text { Pepsin } \\
\text { digestion } \\
(t=120 \mathrm{~min})\end{array}$} & & \multicolumn{2}{c}{$\begin{array}{c}\text { Trypsin } \\
\text { digestion } \\
(t=240 \mathrm{~min})\end{array}$} \\
\cline { 2 - 3 } \cline { 5 - 6 } $\begin{array}{l}\text { Haplotype } \\
\left(\alpha_{\mathrm{S} 1^{-}}, \beta-, \kappa-\mathrm{CN}\right)\end{array}$ & Mean & $\mathrm{SD}$ & & Mean & $\mathrm{SD}$ \\
\hline$B B, A^{2} A^{2}, A B$ & $0.264^{\mathrm{a}}$ & 0.013 & & $0.020^{\mathrm{a}}$ & 0.001 \\
$B B, A^{2} A^{2}, B B$ & $0.942^{\mathrm{b}}$ & 0.052 & & $0.043^{\mathrm{b}}$ & 0.003 \\
$B B, A^{2} A^{2}, A A$ & $0.200^{\mathrm{c}}$ & 0.015 & & $0.021^{\mathrm{a}}$ & 0.002 \\
$B B, A^{1} A^{1}, A A$ & $0.181^{\mathrm{d}}$ & 0.011 & & $0.012^{\mathrm{c}}$ & 0.001 \\
$B B, A^{2} A^{1}, A A$ & $0.213^{\mathrm{c}}$ & 0.015 & & $0.011^{\mathrm{c}}$ & 0.001 \\
\hline
\end{tabular}

$\overline{\mathrm{a}-\mathrm{d}}$ Means within a column with different superscripts differ $(P<0.05)$. ${ }^{1} \mathrm{IC}_{50}=$ concentration needed to inhibit ACE to $50 \%$ of its original activity. 
Table 2. Antioxidant capacity (mg of Trolox equivalent per $\mathrm{mg}$ of casein) of unhydrolyzed casein $(t=0 \mathrm{~min})$, and after in vitro pepsin $(t=$ $120 \mathrm{~min})$ and trypsin $(t=240 \mathrm{~min})$ digestion

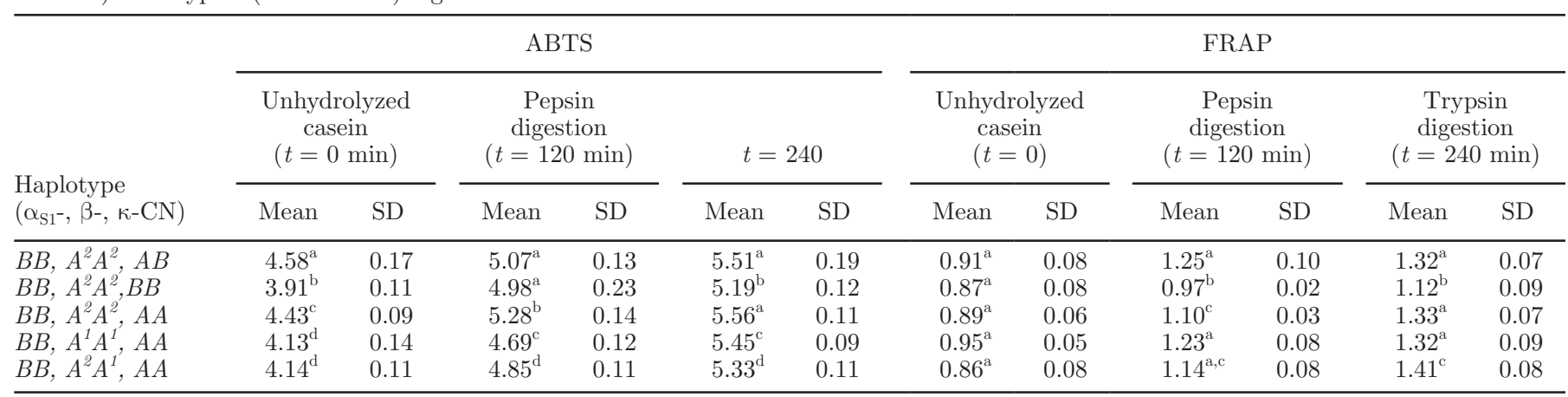

${ }^{\mathrm{a}-\mathrm{c}}$ Means within a column with different superscripts differ $(P<0.05)$.

In conclusion, the results obtained in our study provide useful information for the definition of the bioactive potential associated with the digestion of bovine milk with different casein haplotypes. Angiotensinconverting enzyme-inhibitory and antioxidant capacities greatly increased following in vitro digestion with gastrointestinal enzymes. In particular, after in vitro enzymatic digestion, $B B-A^{2} A^{1}-A A$ casein showed the highest value of ACE inhibition and chelating capacity, whereas $B B-A^{2} A^{2}-A A$ and $B B-A^{2} A^{2}-A B$ caseins showed the highest scavenging capacity. Although more studies are needed to confirm our findings, milk protein polymorphisms represent a crucial element in providing milk with better nutraceutical properties.

\section{REFERENCES}

Adt, I., C. Dupas, R. Boutrou, N. Oulahal, C. Noel, and D. Molle. 2011. Identification of caseinophosphopeptides generated through in vitro gastro-intestinal digestion of Beaufort cheese. Int. Dairy J. 21:129-134.

Alberti-Fidanza, A., G. Burini, and G. Perriello. 2002. Total antioxidant capacity of colostrum, and transitional and mature human milk. J. Matern. Fetal Neonatal Med. 11:275-279.

Aliaga, C., and E. A. Lissi. 2000. Reactions of the radical cation derived from 2,2-azinobis(3- ethylbenzothiazoline-6-sulfonic acid) $($ ABTS $\bullet+)$ with amino acids. Kinetics and mechanism. Can. J. Chem. 78:1052-1059.

Ao, J., and B. Li. 2013. Stability and antioxidative activities of casein peptide fractions during simulated gastrointestinal digestion in vitro: Charge properties of peptides affect digestive stability. Food Res. Int. 52:334-341.

Arcan, I., and A. Yemenicioğlu. 2007. Antioxidant activity of protein extracts from heat-treated or thermally processed chickpeas and white beans. Food Chem. 103:301-312.

Beja-Pereira, A., G. Erhardt, C. Matos, L. Gama, and N. Ferrand. 2002. Evidence of a geographical cline of casein haplotypes in Portuguese cattle breeds. Anim. Genet. 33:295-300.

Benzie, I. F. F., and J. J. Strain. 1996. The ferric reducing ability of plasma (FRAP) as a measure of "antioxidant power": The FRAP assay. Anal. Biochem. 239:70-76.

Boettcher, P. J., A. Caroli, A. Stella, S. Chessa, E. Budelli, F. Canavesi, S. Ghiroldi, and G. Pagnacco. 2004. Effects of casein haplotype on milk production traits in Italian Holstein and Brown Swiss Cattle. J. Dairy Sci. 87:4311-4317.
Caroli, A. M., S. Chessa, and G. L. Erhardt. 2009. Invited review: Milk protein polymorphisms in cattle: Effect on animal breeding and human nutrition. J. Dairy Sci. 92:5335-5352.

Chabance, B., P. Jollès, C. Izquierdo, E. Mazoyer, C. Francoual, L. Drouet, and A. M. Fiat. 1995. Characterization of an antithrombotic peptide from kappa-casein in newborn plasma after milk ingestion. Br. J. Nutr. 73:583-590.

Chabance, B., P. Marteau, J. C. Rambaud, D. Migliore-Samour, M. Boynard, P. Perrotin, R. Guillet, P. Jollès, and A. M. Fiat. 1998. Casein peptide release and passage to the blood in humans during digestion of milk or yogurt. Biochimie 80:155-165.

Colbert, L. B., and E. A. Decker. 1991. Antioxidant activity of an ultrafiltration permeate from acid whey. J. Food Sci. 56:1248-1250.

Conlin, P. R. 2001. Efficacy and safety of angiotensin receptor blockers: A review of Losartan in essential hypertension. Curr. Ther. Res. 62:79-91.

Corrêa, A. P. F., D. J. Daroit, J. Coelho, S. M. Meira, F. C. Lopes, J. Segalin, P. H. Risso, and A. Brandelli. 2011. Antioxidant, antihypertensive and antimicrobial properties of ovine milk caseinate hydrolyzed with a microbial protease. J. Sci. Food Agric. 91:22472254.

De Noni, I., R. J. FitzGerald, H. J. T. Korhonen, Y. Le Roux, C. T. Livesey, I. Thorsdottir, D. Tome, and R. Witkamp. 2009. Review of the potential health impact of $\beta$-casomorphins and related peptides. EFSA Sci. Rep. 231:1-107.

Di Stasio, L., and P. Mariani. 2000. The role of protein polymorphism in the genetic improvement of milk production. Zootec. Nutr. Anim. 26:69-90.

Elias, R. J., S. S. Kellerby, and E. A. Decker. 2008. Antioxidant activity of proteins and peptides. Crit. Rev. Food Sci. Nutr. 48:430-441.

Ferretti, L., P. Leone, and V. Sgaramella. 1990. Long range restriction analysis of the bovine casein genes. Nucleic Acids Res. 18:6829 6833.

Fiat, A. M., and P. Jolles. 1989. Caseins of various origins and biologically active casein peptides and oligosaccharides: Structural and physiological aspects. Mol. Cell. Biochem. 87:5-30.

Gambacorta, E., C. Cosentino, M. Gambacorta, D. Marsico, and A. Perna. 2005. Podolian breed cows: Casein genotype and cheesemaking attitude in pasta filata and in hard pressed curd cheese. Pages 153-162 in Proc. 40th Simp. Intern. Zootec. From Genome to Proteome in Animal Science. Istituto Sperimentale Italiano "Lazzaro Spallanzani," Lodi, Italy.

Gómez-Ruiz, J. Á., I. López-Expósito, A. Pihlanto, M. Ramos, and I. Recio. 2008. Antioxidant activity of ovine casein hydrolysates. Identification of active peptides by HPLC-MS/MS. Eur. Food Res. Technol. 227:1061-1067.

Hajirostamloo, B. 2010. Bioactive component in milk and dairy product. Int. J. Biol. Biomol. Agric. Food Biotechnol. Eng. 4:870-874.

Hernández-Ledesma, B., L. Amigo, M. Ramos, and I. Recio. 2004. Release of angiotensin converting enzyme-inhibitory peptides by simulated gastrointestinal digestion of infant formulas. Int. Dairy J. 14:889-898. 
Hernández-Ledesma, B., B. Miralles, L. Amigo, M. Ramos, and I. Recio. 2005. Identification of antioxidant and ACE-inhibitory peptides in fermented milk. J. Sci. Food Agric. 85:1041-1048.

Jrad, Z., J. M. Girardet, I. Adt, N. Oulahal, P. Degraeve, T. Khorchani, and H. El Hatmi. 2014. Antioxidant activity of camel milk casein before and after in vitro simulated enzymatic digestion. Mljekarstvo 64:287-294.

Lisson, M., G. Lochnit, and G. Erhardt. 2013. Genetic variants of bovine beta- and kappa-casein result in different immunoglobulin Ebinding epitopes after in vitro gastrointestinal digestion. J. Dairy Sci. 96:5532-5543.

López-Expósito, I., A. Quirós, L. Amigo, and I. Recio. 2007. Casein hydrolysates as a source of antimicrobial, antioxidant and antihypertensive peptides. Lait 87:241-249.

Mao, X. Y., X. Cheng, X. Wang, and S. J. Wu. 2011. Free radicalscavenging and anti-inflammatory effect of yak milk casein before and after enzymatic hydrolysis. Food Chem. 126:484-490.

Mao, X. Y., J. R. Ni, W. L. Sun, P. P. Hao, and L. Fan. 2007. Value-added utilization of yak milk casein for the production of angiotensin-I converting enzyme inhibitory peptides. Food Chem. 103:1282-1287.

Martin, P., M. Szymanowska, L. Zwierzchowski, and C. Leroux. 2002. The impact of genetic polymorphisms on the protein composition of ruminants milks. Reprod. Nutr. Dev. 42:433-459.

Maruyama, S., H. Mitachi, H. Tanaka, N. Tomizuka, and H. Suzuki 1987. Angiotensin-I converting enzyme inhibitory activity of the C-terminal hexapeptide of a-casein. Agric. Biol. Chem. 51:25572561

Meisel, H., D. J. Walsh, B. A. Murray, and R. J. FitzGerald. 2006. ACE inhibitory peptides. Pages 269-315 in Nutraceutical Proteins and Peptides in Health and Disease. Y. Mine and F. Shahidi, ed. CRC Press, New York, NY.

Minervini, F., F. Algaron, G. C. Rizello, P. F. Fox, V. Monnet, and M. Gobbetti. 2003. Angiotensin I-converting-enzyme-inhibitory and antibacterial peptides from Lactobacillus helveticus PR4 proteinase-hydrolyzed caseins of milk from six species. Appl. Environ. Microbiol. 69:5297-5305.

Moon, J. K., and T. Shinamoto. 2009. Antioxidant assays for plant and food components. J. Agric. Food Chem. 57:1655-1666.

Ondetti, M. A., and D. W. Cushman. 1977. Design of specific inhibitors of angiotensin-converting enzyme: New class of orally active antihypertensive agents. Science 196:441-444.
Perna, A., I. Intaglietta, A. Simonetti, and E. Gambacorta. 2013. Effect of genetic type and casein aplotype on antioxidant activity of yogurt during storage. J. Dairy Sci. 96:3435-3441.

Petrat-Melin, B., P. Andersen, J. T. Rasmussen, N. A. Poulsen, L. B. Larsen, and J. F. Young. 2015. In vitro digestion of purified $\beta$-casein variants $\mathrm{A} 1, \mathrm{~A} 2, \mathrm{~B}$, and I: Effects on antioxidant and angiotensin-converting enzyme inhibitory capacity. J. Dairy Sci. 98:15-26.

Phelan, M., A. Aherne, R. J. FitzGerald, and N. M. O'Brien. 2009 Casein-derived bioactive peptides: Biological effects, industrial uses, safety aspects and regulatory status. Int. Dairy J. 19:643-654.

Raynes, J. K., L. Day, M. A. Augustin, and J. A. Carver. 2015. Structural differences between bovine $\mathrm{A}^{1}$ and $\mathrm{A}^{2} \beta$-casein alter micelle self-assembly and influence molecular chaperone activity. J. Dairy Sci. 98:2172-2182.

Re, R., N. Pellegrini, A. Proteggente, A. Pannala, M. Yang, and C. Rice-Evans. 1999. Antioxidant activity applying and improved ABTS radical cation decolorization assay. Free Radic. Biol. Med. 26:1231-1237.

Rival, S. G., S. Fornaroli, C. G. Boeriu, and H. J. Wichers. 2001. Caseins and casein hydrolysates. 1. Lipoxygenase inhibitory properties. J. Agric. Food Chem. 49:287-294.

Salami, M., A. A. Moosavi-Movahedi, M. R. Ehsani, R. Yousefi, T. Haertlé, and J. M. Chobert. 2010. Improvement of the antimicrobial and antioxidant activities of camel and bovine whey proteins by limited proteolysis. J. Agric. Food Chem. 58:3297-3302.

SAS Institute. 1996. SAS User's Guide: Statistics. Version 7. SAS Inst. Inc., Cary, NC.

Silva, S. V., and F. X. Malcata. 2005. Caseins as source of bioactive peptides. Int. Dairy J. 15:1-15.

Smacchi, E., and M. Gobbetti. 2000. Bioactive peptides in dairy products: synthesis and interaction with proteolytic enzymes. Food Microbiol. 17:129-141.

Tong, L. M., S. Sasaki, D. J. McClements, and E. A. Decker. 2000. Mechanism of the antioxidant activity of high molecular weight fraction of whey. J. Agric. Food Chem. 48:1473-1478.

Wu, J., R. E. Aluko, and S. Nakai. 2006. Structural requirements of angiotensin 1-converting enzyme inhibitory peptides: Quantitative structure-activity relationship study of di- and tripeptides. J. Agric. Food Chem. 54:732-738. 